\title{
FGR wt Allele
}

National Cancer Institute

\section{Source}

National Cancer Institute. FGR wt Allele. NCI Thesaurus. Code C51113.

Human FGR wild-type allele is located within 1p36.2-p36.1 and is approximately $23 \mathrm{~kb}$ in length. This allele, which encodes proto-oncogene tyrosine-protein kinase FGR protein, is involved in the regulation of outside-in signaling-dependent sustained neutrophil adhesion. Amplification of this gene is associated with the development of hormoneresistant prostate cancer. 